\title{
Effects of different poultry waste manure rates and irrigation intervals on okra (Abelmoschus esculentus L.) growth and yield performance
}

\author{
Ufere N. Uka ${ }^{1 *} \cdot$ Smart U. Nwinyinya ${ }^{1} \cdot$ Kanayo S. Chukwuka ${ }^{2}$
}

${ }^{1}$ Ebonyi State University, Department of Applied Biology, Abakaliki, Nigeria

${ }^{2}$ University of Ibadan, Department of Botany, Ibadan, Nigeria

\begin{abstract}
Summary: The use of organic addition has been found to be an environmentally beneficial method for enhancing quality of crops with good soil quality. Similarly, selection of suitable irrigation period is an important factor for optimum crop production. A study was conducted to evaluate the effects of chicken manure and irrigation interval on the development and production of okra in a greenhouse. The poultry manure was applied to $5 \mathrm{~kg}$ soil at three different rates, namely: $20 \mathrm{t} \mathrm{ha}^{-1}\left(\mathrm{~T}_{1}\right), 40 \mathrm{tha}^{-1}\left(\mathrm{~T}_{2}\right)$, and $60 \mathrm{tha}^{-1}\left(\mathrm{~T}_{3}\right)$, and the fourth group without poultry manure treatment were set up as the control. Four levels of irrigation intervals (3, 6, 9 and 12 days) were selected for the study. Plant height, number of leaves, leaf area $\left(\mathrm{cm}^{2}\right)$, and stem diameter were all assessed as growth metrics. Leaf fresh weight, leaf dry weight, shoot fresh weight, shoot dry weight, root fresh weight, root dry weight, and total plant dry weight were the yield characteristics that were measured. The findings indicated that increasing poultry manure rates enhanced the examined growth and yield parameters, but increasing irrigation intervals decreased the studied growth and yield characteristics of Abelmoschus esculentus. The interplay between chicken manure and irrigation intervals, on the other hand, had no significant effect on leaf area and stem diameter. Finally, the application of $60 \mathrm{t} \mathrm{ha}^{-1}$ poultry manure and a three-day watering interval boosted the development of Abelmoschus esculentus.

Keywords: Abelmoschus esculentus, irrigation, okra, poultry manure, yield
\end{abstract}

\section{Introduction}

Okra (Abelmoschus esculentus (L.) Moench) is a tropical and subtropical annual vegetable that belongs to the Malvaceae family. In addition to being a highly nutritious vegetable, okra has medicinal properties. Many minerals, such as phosphorus, potassium, and sulfur, as well as vitamins A and B can be found in it, along with vitamin C. Okra produces fruits for an extended period of time, necessitating a steady supply of plant nutrients, both macro and micro, for higher yields and better quality. For harnessing the higher yields and better quality, adequate quantities of plant

Corresponding author:

ufere.uka@ebsu.edu.ng

Cite this article:

Uka U. N., Nwinyinya S. U., Chukwuka K. S. (2021). Effects of different poultry waste manure rates and irrigation intervals on okra (Abelmoschus esculentus $\mathrm{L}$.) growth and yield performance. Ratar. Pourt., 58 (3), 80-87.

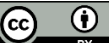

Copyright (C) The Author(s) 202 nutrients are pre-requisites, which can be supplied both by organic and inorganic sources. One of the main obstacles in producing higher yields is insufficient or imbalanced nutrient sources. The continuous and indiscriminate use of inorganic fertilizers has resulted in decreased nutrient uptake and adversely affected the quality of vegetables (Agarwal, 2003). Thus, there is a growing need to use other plant nutrient sources for sustainability of okra production. The answer lies in the use of organic manures, which aims at cooperating rather than confronting with nature. A wide range of organic manures like farm yard manure, sheep manure, poultry manure, composts and bio-fertilizers are used. However, poultry manure is superior and nutritionally rich, as it contains growth promoting substances which induce better plant growth.

Water stress is one of the most significant constraints to crop production, and it is becoming a more serious issue in many parts of the world (Passioura, 2007). Rivalry among various sectors, agricultural, communities, industry, nature, becomes more intense, with agriculture bearing the brunt of the 
demand for precious water resources, since its production per unit water is much lower than that of the other economic sectors. Climate change has caused substantial uncertainty and farming restriction owing to frequent drought occurrences, which has had severe negative consequences on livelihood and food security, particularly for rural people. Because the world water supply is limited, future food and fodder demand for rapidly growing population pressures will likely increase the importance of water stress research (Somerville \& Briscoe, 2001). Water stress reduces leaf size, stems extension, and root proliferation, disrupts plant relationships, and lowers plant water use efficiency (Farooq et al. 2008). Water stress is one of the crop growth and yield limiting factors, reducing dry matter production, yield, and yield components by decreasing leaf area and speeding up leaf senescence (Emam \& Seghatoleslami, 2005).

Drought is a significant factor restricting agricultural output and has resulted in a decline in food production by lowering water and nutrient intake (Du et al. 2010). Climate change and competition from other water users have depleted water resources (Farahani et al. 2007). Irrigation is a reliable approach to mitigate climatic consequences because it is utilized to supplement occasional or irregular rainfall, as well as during dry seasons (Idoga et al. 1998). Okra can grow in poor soils, although it likes well-drained sandy loams with a $\mathrm{pH}$ of 6-7 and high organic matter content (Lamont 1999, Adilakshmi et al. 2008, Akanbi et al. 2010, Akande et al. 2010). In order to develop its young edible fruits over a reasonably long length of time, okra requires a moderate rainfall of $80-100 \mathrm{~cm}$ that is evenly distributed. An ideal temperature range for growth, flowering, and fruiting is $20^{\circ} \mathrm{C}$ to $30^{\circ} \mathrm{C}$ (Akinyele \& Temikotan 2007, Dada \& Fayinminnu 2010). Despite the nutritional quality of these crops, large production is limited to the rainy season owing to scarcity of water supply during off season. In the light of the above and owing to limited literature on the response of Abelmoschus esculentus on poultry waste manure and irrigation, an investigation was carried out to assess the effects of poultry manure and irrigation interval on the growth and yield performance of okra (Abelmoschus esculentus) in a greenhouse.

\section{Material and Methods}

The experiment was carried out at Ebonyi State University Screen House of Biotechnology Research and Development Centre in Abakaliki, Nigeria located on latitude 6'22'26' $\mathrm{N}$ and longitude 8०6'6' E. The average atmospheric temperature was $32-35^{\circ} \mathrm{C}$ (Epidi et al. 2008).

Soil samples were taken using a soil auger at a depth of $0-15 \mathrm{~cm}$. The soil was sieved through a $2 \mathrm{~mm}$ mesh sieve to remove large objects, dead woods and root fragments and was air dried for 7 days. The soil samples weighing $5 \mathrm{~kg}$ were put into plastic pots with a height of
$22 \mathrm{~cm}$ and a diameter of $23.5 \mathrm{~cm}$ with perforations in the bottom for draining of excess water and set in a completely random design. The poultry manure (PM) was applied to the $5 \mathrm{~kg}$ soil at 3 rates, namely: $20 \mathrm{t} \mathrm{ha}^{-1}$ $\left(\mathrm{T}_{1}\right), 40 \mathrm{tha}^{-1}\left(\mathrm{~T}_{2}\right)$, and $60 \mathrm{t} \mathrm{ha}^{-1}\left(\mathrm{~T}_{3}\right)$. The group without poultry manure treatment was set up as the control. Each treatment was replicated four times. These treatments were labeled accordingly. The PM was thoroughly mixed with the $5 \mathrm{~kg}$ soil in the experimental pots and after two weeks of consistent watering in the screenhouse, the plastic pots were weighed 48 hours later to calculate their weight at field capacity based on the assumption that free gravity water had ceased draining (Richard \& Weaver, 1994). In each pot, 4 seeds were planted at a depth of $2.0 \mathrm{~cm}$. The seedlings were thinned down to 2 seedlings per pot after germination and establishment. Water stress was now induced by observing irrigation intervals of 3, 6, 9 and 12 days based on field capacity water content. For 56 days, plant height, leaf length, leaf breadth, stem diameter, number of leaves, and leaf area were all measured on a weekly basis. Plants were separated into leaves, stems, and roots in each replicate. In order to determine dry weight, these were placed in separate envelopes and oven dried for 4 days at $70^{\circ} \mathrm{C}$.

Sandy loam soil samples from each treatment were collected in triplicates, air dried, and sieved through a 2 $\mathrm{mm}$ mesh prior to analysis to remove coarse rock and plant material, and then thoroughly mixed to ensure uniformity. The soil physico-chemical properties of the sieved soil samples were determined using a standard procedure developed by Sertsu \& Bekele (2000).

The data collected were subjected to analysis of variance (ANOVA) at 5\% using SPSS version 23 and the means were separated using Tukey's HSD test.

\section{Results and discussion}

The physico-chemical characteristics of soil receiving different dosage of poultry manure are as presented below (Table 1). The application of waste manure brought about an increase in the organic matter of the soil, and a decrease in the bulk density with no soil textural change. There was an increase in available micronutrients, EC, $\mathrm{pH}, \mathrm{P}, \mathrm{K}, \mathrm{Ca}$ and $\mathrm{Mg}$ in comparison to the control $\left(0 \mathrm{t} \mathrm{ha}^{-1}\right)$. In the treatment receiving 60 tha $^{-1}$, the highest amounts of $\mathrm{N}(0.26 \mathrm{mgkg}$ 1), P (31.30 $\left.\mathrm{mgkg}^{-1}\right), \mathrm{K}\left(0.24 \mathrm{Cmolkg}^{-1}\right), \mathrm{Ca}(8.00 \mathrm{mgkg}-$ 1) were recorded. $\mathrm{Cu}\left(33.20 \mathrm{mgkg}^{-1}\right), \mathrm{Fe}\left(115.95 \mathrm{mgkg}^{-1}\right)$, $\mathrm{Mn}\left(18.34 \mathrm{mgkg}^{-1}\right), \mathrm{Na}\left(0.17 \mathrm{mgkg}^{-1}\right)$ and $\mathrm{Mg}$ (4.65 $\left.\mathrm{mgkg}^{-1}\right)$ were also maximum in the treatment with 60 tha ${ }^{-1}$. The $\mathrm{pH}$ of the soil increased from 5.40 at $0 \mathrm{t} \mathrm{ha}^{-1}$ to 6.70 on application of PM at $60 \mathrm{t} \mathrm{ha}^{-1}$. The soil electrical conductivity increased from 7.40 to 7.56 at 60 tha $\mathrm{a}^{-1}$. There was an increase in the organic matter of the soil from $1.28 \mathrm{mgkg}^{-1}$ to $6 \mathrm{mgkg}^{-1}$ with increasing levels of poultry manure. The textural class of the soil was sandy loam. Soil of this textural class lacks retention capacity for basic nutrients and water (Ukabiala et al. 
2016). The $\mathrm{pH}$ of the soil was slightly acidic and thus could have arisen from the leaching out of basic cations due to frequent irrigation. There was an increase in the micro and macronutrients of the soil on application with of poultry waste manure. These nutrients increased with increase in the quantity applied. Our results are in agreement with Ewulo \& Omoju (2015), Amusan and Ojeniyi (2011), Adekiya et al. (2012), and Voor et al. (2018). The addition of poultry manure to soil increases soil organic matter, $\mathrm{N}$ and $\mathrm{P}$, and aggregate stability, creating a favorable environment for biological processes in the rhizosphere and nutrient availability for plants (Adesodun et al. 2005, Valiki et al. 2015). The increase in soil organic matter may be responsible for the enhanced availability of total $\mathrm{N}$, bioavailable $\mathrm{P}$, exchangeable $\mathrm{K}, \mathrm{Ca}$, and $\mathrm{Mg}$ found with increasing rates of poultry manure. This is due to the fact that soil organic matter has been widely reported as a reservoir of many plant nutrients, implying that plant nutrients are inextricably linked to it (Robertson et al. 2004, Raper 2009).

The application of PM increased soil $\mathrm{pH}$, which could be due to increased organic matter content in the soil. This supports Magdoff (1998) that organic matter serves as a source of plant nutrients, has a high cation exchange capacity, and acts as a $\mathrm{pH}$ buffer in the soil. Our results agree with Voor et al. (2018), but are contrary to the previously published report on maize (Ewulo \& Omoju, 2015). The poultry manure release of specific exchangeable bases is responsible for the rise in soil $\mathrm{pH}$ caused by poultry manure application. This supports the findings of Nottidge et al. (2010), who discovered a significant increase in soil $\mathrm{pH}$ as a result of an increase in exchangeable bases after the addition of organic amendments. Similarly, other researchers
(Marschner 1995, Walker et al. 2005) reported significant changes in soil $\mathrm{pH}$ as a result of organic matter oxidation and $\mathrm{CO}_{2}$ emission in the soil after the addition of organic material.

The growth and yield characteristics of Abelmoschus esculentus grown at different poultry waste amendment rates at 56 days after sowing (DAS)

The application of the different rates $\left(20 \mathrm{tha}^{-1}\left(\mathrm{~T}_{1}\right)\right.$, $40 \mathrm{t} \mathrm{ha}^{-1}\left(\mathrm{~T}_{2}\right)$, and $\left.60 \mathrm{t} \mathrm{ha}^{-1}\left(\mathrm{~T}_{3}\right)\right)$ of PM positively increased okra growth characteristics to a varying degree compared with the control $\left(\mathrm{T}_{0}\right)$. There were significant variations $(p<0.05)$ on okra plant height, number of leaves, leaf area and stem diameter due to PM application rates (Table 2). The highest plant height, number of leaves, leaf area and stem diameter mean values of 32.14, 7.67, 91.37 and 495.87 respectively of okra plants in pots treated with $60 \mathrm{t} \mathrm{ha}^{-1}$ $\left(\mathrm{T}_{3}\right)$ were observed and it was statistically comparable to plants in pots treated with $20 \mathrm{t} \mathrm{ha}^{-1}\left(\mathrm{~T}_{1}\right)$ and the control $\left(\mathrm{T}_{0}\right)$ (Table 2$)$. The effect of poultry manure on the yield of Abelmoschus esculentus is as shown in Table 3. The yields of Abelmoschus esculentus were significantly affected in all the treatments $(\mathrm{p}<0.05)$. In terms of leaf fresh weight, leaf dry weight, shoot fresh weight, shoot dry weight, root fresh weight, root dry weight, and total plant dry weight, the poultry waste manure application rate $60 \mathrm{t} \mathrm{ha}^{-1}\left(\mathrm{~T}_{3}\right)$ yielded the highest mean yield of 5.23 , $0.82,16.48,3.29,1.41,0.51$, and 3.80. The mean yield values for the control $\left(\mathrm{T}_{\mathrm{o}}\right)$ were the lowest. The organic modifications of the soil, as well as the supply of nutrients for crops, are driving factors for the application of PM. The improved morphological development of okra must be attributed to the plant's

Table 1. The impact of poultry waste manure on soil physicochemical properties

\begin{tabular}{|c|c|c|c|c|c|}
\hline Element & Unit & $\mathrm{T}_{0}$ & $\mathrm{~T}_{1}$ & $\mathrm{~T}_{2}$ & $\mathrm{~T}_{3}$ \\
\hline Textural class & - & Sandy loam & Sandy loam & Sandy loam & Sandy loam \\
\hline $\mathrm{pH}$ & - & 5.40 & 5.60 & 6.10 & 6.70 \\
\hline Electrical conductivity & $\mathrm{d} S \mathrm{~m}^{-1}$ & 7.40 & 7.45 & 7.48 & 7.56 \\
\hline Bulk density & $\mathrm{gmcm}^{-3}$ & 0.89 & 0.73 & 0.70 & 0.70 \\
\hline Calcium & $\mathrm{mgkg}^{-1}$ & 4.80 & 6.48 & 6.79 & 8.00 \\
\hline Magnesium & mgkg-1 $^{-1}$ & 2.58 & 4.00 & 4.30 & 4.65 \\
\hline Organic matter & $\mathrm{mgkg}^{-1}$ & 1.28 & 1.40 & 5.00 & 6.00 \\
\hline Total N & $\operatorname{mgkg}^{-1}$ & 0.08 & 0.13 & 0.17 & 0.26 \\
\hline Available P & $\mathrm{mgkg}^{-1}$ & 21.00 & 27.00 & 27.98 & 31.30 \\
\hline Copper & $\operatorname{mgkg}^{-1}$ & 13.38 & 19.76 & 24.61 & 33.20 \\
\hline Iron & mgkg-1 $^{-1}$ & 69.90 & 88.96 & 94.55 & 115.95 \\
\hline Manganese & $\operatorname{mgkg}^{-1}$ & 6.97 & 8.98 & 13.69 & 18.34 \\
\hline Sodium & Cmolkg-1 $^{-1}$ & 0.07 & 0.14 & 0.16 & 0.17 \\
\hline Potassium & $\mathrm{Cmolkg}^{-1}$ & 0.121 & 0.13 & 0.22 & 0.24 \\
\hline
\end{tabular}


easy availability and best conditions for quick absorption by the roots. Poultry manure has been shown to improve the vegetative growth of okra due to its high nutrient content, rapid mineralization, optimal $\mathrm{C} / \mathrm{N}$ ratio, nitrogen availability, and growth promoting substances. Earlier studies have found similar positive effects of PM (Onwu et al. 2014, Tiamiyu et al. 2012, Ali et al. 2014, Voor et al. 2018). According to Uka et al. (2013), using poultry droppings resulted in plants with the greatest plant height, leaf area, and fresh weight.

Effects of irrigation days on Abelmoschus esculentus growth and yield characteristics

The analyses of observations showed that different irrigation days responded differently to growth characteristics of okra. Irrigation intervals (water stress) had a significant $(\mathrm{p}<0.05)$ effect on all growth parameters studied. The results showed reduction in the values of the parameters when compared with control (3 days) resulting from increasing irrigation intervals (3 days $>6$ days $>9$ days $>12$ days irrigation intervals). In comparison to the 6,9 , and 12 day-period irrigation, irrigation every three days significantly increased mean okra plant height, number of leaves, leaf area, and stem diameter (31.03, 7.35, 109.97, and 512.38), respectively
(Table 2). The irrigation interval had a significant $(\mathrm{p}<0.05)$ effect on yield in the test crop Abelmoschus esculentus. When irrigated every three days, okra plants had the highest mean leaf fresh weight $(4.29 \mathrm{~g})$, leaf dry weight $(0.88 \mathrm{~g})$, shoot fresh weight $(20.87 \mathrm{~g})$, shoot dry weight $(3.58 \mathrm{~g})$, root fresh weight $(1.81 \mathrm{~g})$, root dry weight $(0.59 \mathrm{~g})$, and total plant dry weight $(4.17 \mathrm{~g})$, and lowest when irrigated every 12 days (Table 3 ). The results of this study are similar to those reported by AlUbaydi et al. (2017), Ghannad et al. (2014a), but contrary to Habtamu et al. (2014) who reported that an increase in plant height as irrigation interval increases from 3 to 6 days and a gradual decrease after 6 days and a maximum number of leaves at 6 days irrigating frequency. According to Guiterrez-Boen \& Thomas (1999), a decrease in soil water availability influences the velocity of diffusion of numerous plant nutrients, and thus their composition and concentration. Similarly, Schaff \& Skogley (1982) found that the lack of water reduced the diffusive transport of numerous plant nutrients to the root system. A significant decrease in nutrient uptake has been recorded during periods of water stress (Marschner 1995), due to decreased ion transport to the root. Abd-El-Kader et al. (2010) observed a reduction in the morphological

Table 2. Effects of different poultry manure amendment rates and irrigation days on the growth characteristics of Abelmoscbus esculentus at $56 \mathrm{DAS}$

\begin{tabular}{ccccc}
\hline \multirow{2}{*}{ Treatment } & \multicolumn{4}{c}{ Growth characteristics } \\
\cline { 2 - 4 } & Plant height $(\mathrm{cm})$ & Number of leaves & Leaf area $\left(\mathrm{cm}^{2}\right)$ & Stem diameter $(\mathrm{mm})$ \\
\hline $\mathrm{T}_{0}$ & $17.73 \pm 1.47^{\mathrm{a}}$ & $4.58 \pm 0.47^{\mathrm{a}}$ & $21.67 \pm 4.38^{\mathrm{a}}$ & $240.08 \pm 28.93^{\mathrm{a}}$ \\
$\mathrm{T}_{1}$ & $25.18 \pm 1.08^{\mathrm{b}}$ & $6.48 \pm 0.39^{\mathrm{b}}$ & $42.31 \pm 6.55^{\mathrm{b}}$ & $374.22 \pm 27.07 \mathrm{~b}$ \\
$\mathrm{~T}_{2}$ & $29.22 \pm 0.98^{\mathrm{c}}$ & $7.20 \pm 0.40^{\mathrm{b}}$ & $85.55 \pm 11.75^{\mathrm{c}}$ & $454.95 \pm 29.13^{\mathrm{bc}}$ \\
$\mathrm{T}_{3}$ & $32.14 \pm 1.13^{\mathrm{c}}$ & $7.67 \pm 0.42^{\mathrm{b}}$ & $91.37 \pm 12.31^{\mathrm{c}}$ & $495.87 \pm 31.85^{\mathrm{cc}}$ \\
\hline & & & $512.38 \pm 31.74^{\mathrm{a}}$ \\
\hline Irrigation interval & $31.03 \pm 1.27^{\mathrm{a}}$ & $7.35 \pm 0.39 \mathrm{a}$ & $109.97 \pm 14.42^{\mathrm{a}}$ & $425.20 \pm 26.65^{\mathrm{ab}}$ \\
3rd day & $28.54 \pm 1.04^{\mathrm{a}}$ & $7.03 \pm 0.40^{\mathrm{a}}$ & $67.38 \pm 9.79^{\mathrm{b}}$ & $345.25 \pm 29.58^{\mathrm{bb}}$ \\
6th day & $23.37 \pm 1.29^{\mathrm{b}}$ & $6.13 \pm 0.45^{\mathrm{ab}}$ & $32.74 \pm 4.12^{\mathrm{c}}$ & $282.30 \pm 31.19 \mathrm{bb}$ \\
\hline 12th day & $21.32 \pm 1.45^{\mathrm{b}}$ & $5.42 \pm 0.49^{\mathrm{bb}}$ & $30.81 \pm 4.42^{\mathrm{c}}$ & \\
\hline
\end{tabular}

At $5 \%$, the means in a column followed by the same letters do not differ significantly $(\mathrm{P}<0.05)$

Table 3. Effect of poultry manure and irrigation days on yield of Abelmoschus esculentus at 56 DAS

\begin{tabular}{|c|c|c|c|c|c|c|c|}
\hline \multirow[b]{2}{*}{ Treatment } & \multicolumn{7}{|c|}{ Yield } \\
\hline & $\begin{array}{l}\text { Leaf fresh } \\
\text { weight }(g)\end{array}$ & $\begin{array}{l}\text { Leaf dry } \\
\text { weight (g) }\end{array}$ & $\begin{array}{l}\text { Shoot fresh } \\
\text { weight }(\mathrm{g})\end{array}$ & $\begin{array}{l}\text { Shoot dry } \\
\text { weight (g) }\end{array}$ & $\begin{array}{l}\text { Root fresh } \\
\text { weight }(g)\end{array}$ & $\begin{array}{l}\text { Root dry } \\
\text { weight (g) }\end{array}$ & $\begin{array}{l}\text { Total Plant } \\
\text { dry weight }(\mathrm{g})\end{array}$ \\
\hline$\overline{\mathrm{T}_{0}}$ & $1.54 \pm 0.40^{\mathrm{a}}$ & $0.24 \pm 0.07 \mathrm{a}$ & $6.43 \pm 1.74 a$ & $1.27 \pm 0.36 \mathrm{a}$ & $0.51 \pm 0.19 \mathrm{a}$ & $0.16 \pm 0.05^{\mathrm{a}}$ & $1.43 \pm 0.41^{\mathrm{a}}$ \\
\hline $\mathrm{T}_{1}$ & $2.23 \pm 0.36^{\mathrm{a}}$ & $0.36 \pm 0.09 a$ & $9.49 \pm 2.46^{\mathrm{ab}}$ & $1.70 \pm 0.30^{\mathrm{ab}}$ & $0.88 \pm 0.26^{\mathrm{ab}}$ & $0.23 \pm 0.07 \mathrm{ab}$ & $1.93 \pm 0.36^{\mathrm{a}}$ \\
\hline $\mathrm{T}_{2}$ & $3.81 \pm 0.21^{b}$ & $0.71 \pm 0.11^{\mathrm{b}}$ & $14.38 \pm 2.65^{\mathrm{ab}}$ & $2.24 \pm 0.36 \mathrm{ab}$ & $1.08 \pm 0.25^{\mathrm{ab}}$ & $0.42 \pm 0.08 \mathrm{bbc}$ & $2.66 \pm 0.44 \mathrm{ab}$ \\
\hline $\mathrm{T}_{3}$ & $5.23 \pm 0.36^{c}$ & $0.82 \pm 0.11^{\mathrm{b}}$ & $16.48 \pm 3.26^{\mathrm{bb}}$ & $3.29 \pm 0.63^{\mathrm{bb}}$ & $1.41 \pm 0.19 \mathrm{bb}$ & $0.51 \pm 0.08 \mathrm{cc}$ & $3.80 \pm 0.71 \mathrm{bb}$ \\
\hline \multicolumn{8}{|c|}{ Irrigation interval } \\
\hline 3rd day & $4.29 \pm 0.49 \mathrm{a}$ & $0.88 \pm 0.10^{\mathrm{a}}$ & $20.87 \pm 2.39 \mathrm{a}$ & $3.58 \pm 0.54 \mathrm{a}$ & $1.81 \pm 0.12^{\mathrm{a}}$ & $0.59 \pm 0.06^{a}$ & $4.17 \pm 0.60^{a}$ \\
\hline 6th day & $3.56 \pm 0.47 \mathrm{ab}$ & $0.62 \pm 0.12 \mathrm{a}^{\mathrm{b}}$ & $14.28 \pm 1.55^{\mathrm{b}}$ & $2.64 \pm 0.19 \mathrm{a}$ & $1.19 \pm 0.13^{b}$ & $0.38 \pm 0.07 \mathrm{~b}$ & $3.01 \pm 0.26^{a}$ \\
\hline 9th day & $2.99 \pm 0.65^{\mathrm{ab}}$ & $0.39 \pm 0.08 \mathrm{bbc}$ & $8.41 \pm 1.49 c$ & $1.51 \pm 0.23 \mathrm{~b}$ & $0.55 \pm 0.15^{c}$ & $0.22 \pm 0.05^{b c}$ & $1.73 \pm 0.28^{\mathrm{b}}$ \\
\hline 12th day & $1.97 \pm 0.58^{\mathrm{bb}}$ & $0.24 \pm 0.07 \mathrm{c}$ & $3.22 \pm 0.78^{c}$ & $0.78 \pm 0.21^{b}$ & $0.31 \pm 0.11^{\mathrm{c}}$ & $0.13 \pm 0.04^{c}$ & $0.90 \pm 0.25^{\mathrm{b}}$ \\
\hline
\end{tabular}

Mean + SE in the same column with different letters in superscript differs significantly $(\mathrm{P}<0.05)$ 
Table 4. Interactive effect of poultry manure amended soil and irrigation days on selected growth characteristics of Abelmoschus esculentus

\begin{tabular}{|c|c|c|c|c|c|}
\hline Treatment & Irrigation days & Plant height $(\mathrm{cm})$ & Leaf number & Leaf area $\left(\mathrm{cm}^{2}\right)$ & Stem diameter $(\mathrm{mm})$ \\
\hline \multirow[t]{5}{*}{$\mathrm{T}_{0}$} & 3rd day & 26.71 & 6.81 & 50.44 & 407.25 \\
\hline & 6th day & 24.23 & 6.62 & 25.93 & 361.18 \\
\hline & 9th day & 14.91 & 3.87 & 9.23 & 162.12 \\
\hline & 12th day & 5.05 & 1.00 & 1.05 & 29.75 \\
\hline & Mean & 17.72 & 4.57 & 21.66 & 240.07 \\
\hline \multirow[t]{5}{*}{$\mathrm{T}_{1}$} & 3rd day & 28.08 & 6.93 & 87.66 & 454.37 \\
\hline & 6th day & 25.89 & 6.56 & 30.91 & 399.31 \\
\hline & 9th day & 25.45 & 6.43 & 27.37 & 340.43 \\
\hline & 12th day & 21.29 & 6.00 & 23.29 & 302.75 \\
\hline & Mean & $25.18(42.10)$ & $6.48(41.79)$ & 42.31(95.34) & $374.22(55.88)$ \\
\hline \multirow[t]{5}{*}{$\mathrm{T}_{2}$} & 3rd day & 32.43 & 7.68 & 140.50 & 540.81 \\
\hline & 6th day & 30.41 & 7.18 & 104.83 & 482.12 \\
\hline & 9th day & 27.56 & 7.06 & 52.91 & 429.50 \\
\hline & 12th day & 26.45 & 6.87 & 43.93 & 367.37 \\
\hline & Mean & $29.21(16.00)$ & $7.20(11.11)$ & $85.54(102.17)$ & $454.95(21.57)$ \\
\hline \multirow[t]{5}{*}{$\mathrm{T}_{3}$} & 3rd day & 36.90 & 8.00 & 161.28 & 647.06 \\
\hline & 6th day & 33.63 & 7.75 & 107.82 & 458.17 \\
\hline & 9th day & 29.70 & 7.56 & 54.47 & 486.62 \\
\hline & 12th day & 28.33 & 7.37 & 41.90 & 391.62 \\
\hline & Mean & $32.14(10.03)$ & $7.66(6.39)$ & $91.37(6.82)$ & 495.87(8.99) \\
\hline Poultry manure & & $*$ & * & $*$ & $*$ \\
\hline Irrigation days & & $*$ & * & $*$ & $*$ \\
\hline $\begin{array}{l}\text { Poultry manure } X \\
\text { Irrigation days }\end{array}$ & & $*$ & $*$ & NS & NS \\
\hline
\end{tabular}

$* \mathrm{P}<0.05=$ Significant $(\mathrm{)}=$ Percentage Increase

characteristics of okra due to increasing irrigation intervals. The irrigation enables the mineral elements to be dissolved and conveyed to various plant parts and the water is highly imported into the photosynthetic apparatus, making water an important factor affecting plant growth (El-Sahookie et al. 2009).

The effect of irrigation intervals on the growth and yield of okra could be attributed to the plant stomatal activities, which are influenced at these intervals. The intervals between irrigation had an effect on the opening and closing of the stomata, particularly the stomata of the leaf (Anant et al. 2009), and the plant was saved from drought. Reduced plant height, leaf area, yield, and other characteristics at higher irrigation intervals may be due to decreased cell enlargement and increased leaf senescence as a result of reduced turgor pressure (Shao et al. 2008, Farooq et al. 2009), or to decreased photosynthesis and altered canopy structure (Shao et al. 2008). According to Leithy et al. (2006), decreased plant growth is linked to a lower rate of photosynthesis due to deteriorating stomatal behavior. The development of an optimum leaf area for photosynthesis and yield development (Jaleel et al. 2009) is a must, because when the leaf area is smaller, the capacity to capture light decreases, resulting in a lower photosynthesis rate (Khalid 2006) and growth. Furthermore, the impact of reduced irrigation on plant growth could be due to a lack of adequate moisture in the rhizosphere and lower nutrient absorption (Singh et al. 1997). Plant size and growth may be reduced as a result of a decrease in the activity of meristemic tissues responsible for elongation when exposed to water stress (Siddique et al. 1999).

Interactive effect of poultry manure and irrigation days on selected growth characteristics of Abelmoschus esculentus

The interaction between poultry manure amended soil and irrigation days on the growth of Abelmoschus esculentus are presented in Table 4. In okra plant height and number of leaves, the levels of interaction between PM amended soil and irrigation intervals were statistically significant $(\mathrm{p}<0.05)$. The PM application rate $\left(60 \mathrm{tha}^{-1} \mathrm{~T}_{3}\right)$ and the third day irrigation interval produced the tallest and most leafy okra plants. Plant height and number of leaves were significantly $(p<0.05)$ influenced by poultry manure amended soil and irrigation intervals (Table 4). Plant height, number of 
Table 5. Interactive effects of poultry manure and irrigation days on yield of Abelmoschus esculentus

\begin{tabular}{|c|c|c|c|c|c|c|c|c|}
\hline Treatment & $\begin{array}{l}\text { Irrigation } \\
\text { Days }\end{array}$ & $\begin{array}{l}\text { Leaf fresh } \\
\text { weight }(g)\end{array}$ & $\begin{array}{l}\text { Leaf dry } \\
\text { weight (g) }\end{array}$ & $\begin{array}{l}\text { Shoot fresh } \\
\text { weight (g) }\end{array}$ & $\begin{array}{l}\text { Shoot dry } \\
\text { weight }(\mathrm{g})\end{array}$ & $\begin{array}{l}\text { Root fresh } \\
\text { weight (g) }\end{array}$ & $\begin{array}{l}\text { Root dry } \\
\text { weight (g) }\end{array}$ & $\begin{array}{l}\text { Total plant } \\
\text { dry weight (g) }\end{array}$ \\
\hline \multirow{5}{*}{$\mathrm{T}_{0}$} & 3rd day & 2.75 & 0.50 & 11.50 & 2.38 & 1.30 & 0.38 & 2.75 \\
\hline & 6th day & 2.25 & 0.30 & 10.00 & 2.00 & 0.60 & 0.15 & 2.15 \\
\hline & 9th day & 1.15 & 0.18 & 4.20 & 0.70 & 0.13 & 0.10 & 0.80 \\
\hline & 12th day & 0.00 & 0.00 & 0.00 & 0.00 & 0.00 & 0.00 & 0.00 \\
\hline & Mean & 1.54 & 0.24 & 6.43 & 1.27 & 0.51 & 0.16 & 1.43 \\
\hline \multirow{5}{*}{$\mathrm{T}_{1}$} & 3rd day & 3.50 & 0.78 & 19.73 & 2.60 & 1.78 & 0.50 & 3.10 \\
\hline & 6th day & 2.70 & 0.30 & 10.35 & 2.30 & 1.28 & 0.25 & 2.55 \\
\hline & 9th day & 1.75 & 0.20 & 5.00 & 1.28 & 0.30 & 0.10 & 1.38 \\
\hline & 12th day & 0.95 & 0.15 & 2.88 & 0.63 & 0.15 & 0.05 & 0.68 \\
\hline & Mean & $2.23(44.81)$ & $0.36(50.00)$ & $9.49(47.59)$ & $1.70(33.86)$ & $0.88(72.55)$ & $0.23(43.75)$ & $1.93(34.97)$ \\
\hline \multirow{5}{*}{$\mathrm{T}_{2}$} & 3rd day & 4.70 & 1.08 & 23.38 & 3.35 & 2.00 & 0.70 & 4.05 \\
\hline & 6th day & 3.78 & 0.88 & 18.28 & 2.98 & 1.40 & 0.50 & 3.48 \\
\hline & 9th day & 3.50 & 0.60 & 10.88 & 1.68 & 0.60 & 0.30 & 1.98 \\
\hline & 12th day & 3.25 & 0.30 & 5.00 & 0.98 & 0.30 & 0.18 & 1.15 \\
\hline & Mean & $3.81(70.85)$ & $0.71(97.22)$ & $14.38(51.53)$ & $2.24(31.70)$ & $1.08(22.73)$ & $0.42(82.61)$ & $2.66(37.82)$ \\
\hline \multirow{5}{*}{$\mathrm{T}_{3}$} & 3 rd day & 6.20 & 1.18 & 28.88 & 5.98 & 2.18 & 0.80 & 6.78 \\
\hline & 6th day & 5.50 & 1.00 & 18.50 & 3.28 & 1.50 & 0.60 & 3.88 \\
\hline & 9th day & 5.55 & 0.60 & 13.55 & 2.40 & 1.18 & 0.38 & 2.78 \\
\hline & 12th day & 3.68 & 0.50 & 5.00 & 1.50 & 0.78 & 0.28 & 1.78 \\
\hline & Mean & $5.23(37.27)$ & $0.82(15.49)$ & $16.48(14.60)$ & $3.29(46.88)$ & $1.41(30.56)$ & $0.51(21.43)$ & $3.80(42.86)$ \\
\hline \multicolumn{2}{|c|}{ Poultry Manure } & $*$ & $*$ & $*$ & * & * & * & $*$ \\
\hline \multicolumn{2}{|c|}{ Irrigation Days } & * & $*$ & $*$ & $*$ & $*$ & * & $*$ \\
\hline \multicolumn{2}{|c|}{$\begin{array}{l}\text { Poultry Manure } \\
\text { Irrigation Days }\end{array}$} & $*$ & $*$ & $*$ & * & * & * & * \\
\hline
\end{tabular}

$* \mathrm{P}<0.05=$ Significant ()$=$ Percentage Increase

leaves, leaf area, and stem diameter were all highest with $60 \mathrm{t} \mathrm{ha}^{-1}\left(\mathrm{~T}_{3}\right)$ and $3 \mathrm{rd}$ day of irrigation. With respect to plant height (5.05), leaf number (1.00) and area of leaves (1.05), the lowest values were recorded in control $\left(\mathrm{T}_{\mathrm{o}}\right)$ combine with the 12-day irrigation period. The increases in plant height, number of leaves, leaf area, and stem diameter caused by PM amendment and irrigation interval were $38.15 \%, 17.47 \%, 219.75 \%$, and $58.89 \%$, respectively. The interactive effect of $\mathrm{PM}$ amended soil and irrigation days on yield of Abelmoschus esculentus are presented in Table 5. The interaction between PM and irrigation interval was significant $(\mathrm{p}<0.05)$ on yield of Abelmoschus esculentus. Root dry weight and total plant dry weight were obtained with $\mathrm{T}_{3}$ combined with 3 rd day irrigation. The highest values of leaf fresh weight (6.20), leaf dry weight (1.18), shoot fresh weight (28.88) shoot dry weight (5.98), root fresh weight (2.18), root dry weight (0.80) and total plant dry weight (6.78) were recorded with $\mathrm{T}_{3}$ combined at 3 rd day of irrigation. On the other hand, lowest values of $(0.00)$ were recorded for the entire yield studied with $\mathrm{T}_{0}$ combined with 12th day irrigation period. There was an increase of $125.45 \%, 136 \%, 151.13 \%, 67.69 \%, 110.55 \%$ and $146.55 \%$ respectively. Interactive effect of PM amended soil and Irrigation days enhanced the growth and yield of Abelmoschus esculentus. Low water supply levels, 
according to Chemura (2014), highlight the importance of organic manure in regulating soil water for plant use. Similarly, Ibrahim \& El-Samad (2009) reported that increasing the amount of organic manure in the soil reduces water use significantly.

\section{Conclusions}

There was an increase in the micro and macronutrients of the soil on application of poultry waste manure. In the treatment receiving $60 \mathrm{t} \mathrm{ha}^{-1}$, the highest amounts of micro and macronutrients, $\mathrm{pH}$, and electrical conductivity of the soil were observed. Poultry waste manure had a positive effect on Abelmoschus esculentus growth in terms of plant height, number of leaves, leaf area, stem diameter, and yield parameters such as leaf fresh weight, leaf dry weight, shoot fresh weight, shoot dry weight, root fresh weight, root dry weight, and total plant dry weight. Increased irrigation intervals, on the other hand, had a negative impact on Abelmoschus esculentus growth and yield. The use of $60 \mathrm{t}$ $\mathrm{ha}^{-1}$ poultry manure and a three-day irrigation interval will enhance the growth of Abelmoschus esculentus, according to this study.

\section{References}

Abd El-Kader AA, Shaaban SM, Abd El-Fattah MS (2010): Effect of irrigation levels and organic compost on okra plants (Abelmoschus esculentus 1.) grown in sandy calcareous soil. Agriculture and Biology Journal of North America, 1(3): 225-231.

Adekiya AO, Ojeniyi SO, Agbede, TM (2012): Poultry manure effects on soil properties, leaf nutrient status, growth and yield of Cocoyam in a tropical alfisol. Nigerian Journal of Soil Science, 22 (2): 30-39.

Adesodun JK, Mbagwu JSC, Oti N (2005): Distribution of carbon nitrogen and phosphorus in water stable aggregates of an organic waste amended ultisol in southern Nigeria. Bioresource Technol. 96: 509-516.

Adilakshmi A, Korat DM, Vaishnav PR (2008): Effect of organic manures and inorganic fertilizers on insect pests infesting okra. Karnataka. J. Agric. Sci. 21: 287-289.

Agarwal, A. K. (2003): Role of organic enrichers in management of soil salinity. Agrobios, 2: 21-23.

Akanbi WB, Togun AO, Adeliran JA, Ilupeju EAO (2010): Growth dry matter and fruit yields components of okra under organic and Inorganic sources of nutrients. American-Eurasian J. Sustain. Agric. 4: 1-13.

Akande MO, Oluwatoyinbo FI, Makinde EA, Adepoju AS, Adepoju IS (2010): Response of okra to organic and inorganic fertilization. Nature Sci. 8: 261-266.

Akinyele, BO, Temikotan T (2007): Effect of variation in soil texture on the vegetative and pod characteristics of okra (Abelmoschus esculentus (L.) Moench). Intern. J. Agric. Res. 2: 165-169.

Ali MB, Lakun HI, Sani SM, Adamu HM (2014): Effect of organic manure and sowing date on the growth and yield of okra (Abelmoschus esculentus) in Samaru, Nigeria. International Journal of Agronomy and Agricultural Research, 5(5): 111-117.

Al-Ubaydi RM, Al-Shakry EF, Al-Samara MA, Al-Mohmadawy SM (2017): Effect of irrigation intervals on growth, flowering and fruits quality of Okra Abelmoschus esculentus (L.)Monech. African Journal of Agricultural Research, 12(23): 2036-2040.

Amusan AO, Ojeniyi SO (2011): Effect of integrated application of soil amendments on nutrient uptake and soil properties in a tropical alfisol. Nigerian Journal of Soil Science, 21(2): 24-33.
Anant B, Singh KP, Ashutosh R, Ajay MR (2009): Physiological and Yield Response of okra (Abelmoschus esculentus L.) to irrigation scheduling and organic mulching. Indian J. Agric. Sci. 79(1): 813815.

Chemura A ((2014): The growth response of coffee (Coffea arabica L) plants to organic manure, inorganic fertilizers and integrated soil fertility management under different irrigation water supply levels. Int J Recycl Org W aste Agricult, 3: 59.

Dada OA and Fayinminnu OO (2010): Period of weed control in okra [Abelmoschus esculentus (L.) Moench] as influenced by varying rates of cattle dung and weeding regimes. Notulae Botanicae Horti Agrobotanici Cluj-Napoca, 38: 149-154

Du NW, Guo X, Zhang J, Wang R (2010): Morphological and physiological responses of Vitex negundo L.var. heterophylla (Franch.) Rhd to drought stress. Acta Physiology of Plant. 32: 839848.

El-Sahookie MM, Alfalahi AO, Almehemidi AF (2009): Crop and soil management and breeding for drought tolerance. Iraqis Journal Agriculture Science, 40(2): 1-28.

Emam Y, Seghatoleslami M J (2005): Crop Yield: Physiology and Processes. 1st ed. Shiraz (Iran): Shiraz University Inc. (in Farsi) p. 593.

Epidi TT, Nwani CD, Ugorji NP (2008): Prevalence of malaria in blood donors in Abakaliki Metropolis, Nigeria. Scientific Research and Essay, 3(4): 162-164.

Ewulo BS, Omoju, OJ (2015): Effect of Poultry Manure and Irrigation Interval on Soil Properties And Maize Performance In Akure, Southwest Nigeria. Journal of Organic Agriculture and Environment, 3: 15 $-25$

Farahani HJ, Howell TA, Shuttleworth WJ, Bausch WC (2007): Evapotranspiration process in measurement and modeling in agriculture. American Soci. Afric. Biol. Eng. 50: 1627-1638.

Farooq M, Basra SMA, Wahid A, Cheema ZA, Cheema MA, Khaliq, A (2008): Physiological role of exogenously applied glycinebetaine in improving drought tolerance of fine grain aromatic rice (Oryza sativa L.). Journal of Agronomy and Crop Science, 194: 325333.

Farooq M, Wahid A, Kobayashi N, Fujita D, Basra SMA. (2009): Plant drought stress: effects, mechanisms and management. Agron Sustain Dev. 29: 185-212.

Ghannad M, Madani H, Darvishi HH (2014a): Effect of different sowing times, irrigation intervals and sowing methods on Okra (Abelmoschus esculentus L. Moench). International Journal of Farm Allied Science, 3(6): 683-689.

Ghannad M, Madani H, Darvishi HH (2014b): The response of Okra crop to sowing times, interval and sowing methods in shahrood region. International Journal of Agriculture and Crop Science, 7(10): 676682.

Guitierrez-Boem FH, Thomas GW (1999). Phosphorus nutrition and water deficits in field grown soya beans. American Journal of Soil Science, 207: 87-96.

Habtamu A, Ibrahim A, Hamza BT, Dagmawit D, Bogale A, Damene T (2014): Emergence and seedling growth of Corn (Zea mays L.) as influenced by irrigation schedules on Vertisol. International Research Journal of Plant Science, 5(1): 17-22.

Ibrahim, A. \& El-Samad, G. (2009): Effect of different irrigation regimes and partial substitution of $\mathrm{N}$-mineral by organic manures on water use, growth and productivity of Pomegranate trees. EurJ Sci Res, 38 (2): 199-218.

Idoga S, Adogoye MS, Ogbonnaya JM (1998): Changing climatic conditions and agricultural production implication in Benue State, Nigeria. Proceedings of the 23rd Annual Conference of Soil Science Society of Nigeria, April 12-16: 59-62.

Jaleel CA, Manivannan P, Wahid A, Faroog M, Al-juburi HJ, Somasundaram R, Panneerselvam, R (2009): Drought stress in plants: a review on morphological characteristics and pigments composition. Int J Agric Biol, 11(1): 100-105.

Khalid KA (2006): Influence of water stress on growth, essential oil, and chemical composition of herbs (Ocimumsp.). Int. Agrophys, 20: 289296.

Lamont W (1999): Okra a versatile vegetable crop. Hort. Technol. 9: 179184 
Leithy S, El-Meseiry TA, Abdallah EF. (2006): Effect of biofertilizer, cell stabilizer and irrigation regimen rosemary herbage oil quality. $J$ Appl. Sci, 2: 773-779.

Magdoff F (1998): Nutrient management: Sustainable agriculture research and education program. Bulletin Michigan State University/Extension, 672.

Marschner H (1995): Mineral Nutrition of Higher Plants. Academic Press International, San Diego, CA, USA.

Nottidge DO, Ojeniyi SO, Nottidge CC (2010): Grain legumes residues effects on soil physical conditions, growth and grain yield of maize in an Ultisol. Nigerian Journal of Soil Science, 20(1): 150-153.

Onwu AC, Abubakar JR, Unah PO (2014): Effect of poultry manure on growth, yield of okra and soil properties in Makurdi, North Central Nigeria. International Journal of Agricultural and Food Science, 1: 22498516.

Passioura JB (2007): The drought environment: physical, biological and agricultural perspectives. Journal of Experimental Botany, 58 (2): 113117.

Raper SR. (2009): Organo-mineral fertilizers in crop production in the tropics. International

Richards LA, Weaver LR. (1994): Moisture retention by some irrigated soils as related to soil moisture tension. Journal Agric Research, 69: 215235.

Robertson EA, Atiri A, Liang Y, Hill E (2004): Soil and fertilizer use in the tropics. Biology and Fertility of Soils, 18: 240-246.

Sertsu S, Bekele T (2000): Procedures for soil and plant analysis. National Soil Research Center. EARO, Addis Ababa, pp 15-23.

Shaff BE, Shogley ED (1982): Diffusion of potassium, calcium, and magnesium in bozeman silt loam as influenced by temperature and moisture. Soil Science Society of American Journal, 46: 521-696.

Shao HB, Chu LY, Jaleel CA, Zhao CX (2008): Water-deficit stressinduced anatomical changes in higherplants. Comptes Rendus Biol, 331: 215-225.
Siddique MR, Hamid B, Islam MS (1999): Drought stress effect on photosynthetic rate and leaf gas exchange of wheat. Botanical Bull of Academic Sinica, 40(20): 141-145.

Singh M, Ganesha-rao, R.S, Ramesh S (1997): Irrigation and nitrogen requirement of lemongrass (Cymbopogon flexuosus(Sleud) Wats) on a red sandy loam soil under semiarid tropical conditions. J Essent Oil Res, 9: 569-574.

Somerville C, Briscoe J. (2001): Genetic engineering and water. Science, 292: 2217.

Tiamiyu RA, Ahmed HG, Muhammad AS (2012): Effect of sources of organic manure on growth and yields of okra (Abelmoschus esculentusL.) in Sokoto, Nigeria. Nigerian Journal of Basic and Applied Science, 20(3): 213-216.

Uka UN, Chukwuka KS, Iwuagwu M. (2013): Relative effect of organic and inorganic fertilizers on the growth of okra [Abelmoschus esculentus (L.) Moench]. Journal of Agricultural Sciences, 58(3): 159-166.

Ukabiala ME, Kefas PK, Akpan-Idiok AU, Philip HJ, Ngasoh FG, Kefas AP (2016): Assessment of the physicochemical characteristics, degradation rate and vulnerability potential of Ihitte/Uboma soils, Imo State, Nigeria. International Journal of Agriculture and Environmental Research, 2(5): 1467-1479.

Valiki SRH, Ghanbari S, Akbarzadeh M, Alamdari, MG, Golmohammadzadeh S (2015): Effect of organic and chemical fertilizers on dry yield, essential oil and compounds on rosemary (Rosemarinus officinalis L.). Biol Forum - Int J, 7: 773-782.

Voor VM, Nkansah GO, Smith MS, Page ZC, Luther Z (2018): Effects of Different Water Regimes and Poultry Manure on Growth, Development and Yield of Hot Pepper (Capsicum annum L.). American Scientific Research Journal for Engineering, Technology and Sciences, 44(1): 32-57.

Walker DJ, Clemente R, Bernal MP (2005): Contrasting effects of manure and compost on soil $\mathrm{pH}$, heavy metal availability and growth of Chenopodium album I. In a soil contaminated by pyritic mine waste. Chemosphere, 57: 215-224.

\section{Uticaj različitih doza živinskog stajnjaka i navodnjavanja na rast i prinos bamije (Abelmoschus esculentus L.)}

\section{Ufere Uka $\cdot$ Smart Nwinyinya $\cdot$ Kanayo Chukwuka}

Sažetak: Istraživanje je sprovedeno na Državnom univerzitetu Ebonyi, Abakaliki, Nigerija u cilju ocene uticaja živinskog stajnjaka i navodnjavanja na razvoj i proizvodnju bamije u stakleniku. Živinski stajnjak je dodat u $5 \mathrm{~kg}$ zemljišta u tri različite doze: $20 \mathrm{t} \mathrm{ha}^{-1}\left(\mathrm{~T}_{1}\right), 40 \mathrm{t} \mathrm{ha}^{-1}\left(\mathrm{~T}_{2}\right)$ i $60 \mathrm{t} \mathrm{ha} \mathrm{a}^{-1}\left(\mathrm{~T}_{3}\right)$, a četvrta grupa bez živinskog stajnjaka je bila kontrola. Periodi navodnjavanja useva su bili 3, 6, 9 i 12 dana. Merene su sledeće karakteristike: visina bilike, broj listova, lisna površina $\left(\mathrm{cm}^{2}\right)$ i prečnik stabljike, lisna masa, masa izdanka, masa korena, ukupna suva masa. Rezultati su pokazali da je viša doza živinskog stajnjaka povećala rast i prinos bamije, ali povećanje perioda navodnjavanja je smanjilo rast $\mathrm{i}$ prinos biljaka. Kombinacija $60 \mathrm{t} \mathrm{ha}^{-1}$ živinskog stajnjaka $\mathrm{i}$ trodnevni period navodnjavanja je pogodovao razvoju bamije.

Ključne reči: Abelmoschus esculentus, bamija, navodnjavanje, prinos, živinski stajnjak

This article is distributed under the terms of the Creative Commons Attribution 4.0 International License (http://creativecommons.org/licenses/by/4.0), which permits unrestricted use, distribution and reproduction in any medium, provided you give appropriate credit to the original author(s) and the source, provide a link to the Creative Commons license, and indicate if changes were made. 